№ 2 (4), 2020

УДК 711. 364-1(332.5)

\title{
Олександра Сільник
}

доцент кафедри архітектури і планування сільських поселень, Львівський національний аграрний університет, Дубляни e-mail: silnikoleksandra@gmail.com orcid: 0000-0003-4546-3319

\section{ТЕНДЕНЦІї РОЗВИТКУ ТА НАПРЯМКИ РЕНОВАЦІЇ СІЛЬСЬКИХ ПОСЕЛЕНЬ УКРАЇНИ}

() Сільник O., 2020

https://doi.org/10.23939/sa2020.02.178

У представленій статті висвітлено основні напрямки розвитку украйнських сільських поселень протягом XX ст., культурно-побутову інфраструктуру та архітектурно-планувальні вирішення поселень. Висвітлено проблеми й напрямки ̈̈х вирішення у сучасному розвитку сільських населених пунктів Украйни.

Ключові слова: село, сельбищні території, архітектурно-планувальна структура, культурно-побутова інфраструктура, сільське поселення, реновація.

\section{Постановка проблеми}

Сільське поселення займає досить важливе місце в сучасній соціально-культурній структурі нашої держави. Україна має величезний аграрний потенціал, і розвиток сіл суттєво впливає на економічну ситуацію. Низка історичних етапів відобразилась навіть руйнівними подіями як у веденні господарства, так і в соціально-культурнуму житті селян. Сучасні реформи та програми націлені на відродження господарської діяльності села та підвищення рівня життя його мешканців. Проте, сільське господарство для молодих цілеспрямованих громадян сьогодні не є привабливим. Минулий досвід розбудови населених пунктів свідчить про важливість грунтовного аналізу існуючої забудови, культурної спадщини, а також природно-кліматичних особливостей місцевості.

Мета і завдання статті - висвітлити основні закономірності, що вплинули на розвиток сільських поселень та виявити тенденції архітектурно-планувальних рішень в умовах реновації села.

\section{Аналіз останніх досліджень і публікацій}

Дослідження в галузі сільського господарства активно ведуться спеціалістами в різних наукових напрямках економістами-аграріями (Костюченко Д., 2017; Мазур А., 2016; Bamidele А., 1990), архітекторами (Габрель М. М., 2004; Гнесь Л. Ю., 2017; Лоїк Г. К., 2003; Маханько Б. А., 1982; Сільник О. І., 2018), соціологами та іншими науковцями.

\section{Обговорення проблеми}

Важливим чинником у розвитку сільського господарства $€$ звісно ж зростання якості рівня життя його мешканців. На комфортність сільських поселень впливає якість самого житла, рівень культурно-побутової та виробничої інфраструктури. Для вирішення поставлених цілей важливим $є$ 
врахування культурно-історичної спадщини, особливостей рельєфу і ландшафту та врахування збережених традицій. Вітчизняний та закордонний досвід підтверджує важливість розвитку сільського підприємництва, сфери послуг, освіти культури. Сучасні технічні можливості певним чином спрощують багато виробничих процесів у сільськогосподарській галузі, проте вони вимагають модернізації існуючих поселень. Динамічні процеси модернізації вже мали місце у розвитку сіл пострадянського простору. Вирішення питань благоустрою та реконструкції поселень залишили за собою багато елементів, які мали за мету їх “типізувати”. Такий напрямок діяльності був спрямованим на створення нових генпланів, де передбачалось переважно регулярне розпланування вулиць, інколи, без врахування існуючих природно-кліматичних особливостей, руйнуванням сакральних та культурних спадків, деформації господарської діяльності селян. Відбувалось створення та укрупнення територій з виробничим призначенням сільського господарства (створення колгоспів, радгоспів). У сільських поселеннях Радянського союзу 3'явились громадські центри, що складались 3 адміністративних будівель, клубів, торгових центрів і обов'язково громіздких монументів. Велось масове будівництво типових проектів виробничих та адміністративних споруд по всій країні, і сьогодні, села мають низку недбалого спадку, що свідчить про недоречність певної забудови (рис. 1). Часто одна і та ж планувальна композиція, яка складалась 3 типового набору громадських будівель повторювалась у селах різних кліматичних регіонів, де були свої традиції та ментальні особливості населення. У діяльності масштабних новостворених сільськогосподарських виробничих комплексів відбувались складні процеси, що в результаті вплинули на занепад і руйнування великої кількості сіл. Відповідно, типовість у забудові українських поселень не завжди була доречною, якщо врахувати суттєві природно-кліматичні відмінності. Такий підхід до розпланування не враховував індивідуальності просторового вирішення територій, що вже були сформовані, та створював багато несприятливих чинників, які ніяк не впливали для розвитку, як забудови сельбищної території, так і ведення господарства. В таких умовах занепадало приватне господарство селян, втрачались традиційні навики набуті поколіннями селянських родин.

На цьому етапі науковці поняття “сільські території” тлумачать як складну багатофункціональну природну, соціально-економічну й виробничо-господарську систему 3 властивими їй кількісними, структурними, природними й іншими характеристиками. Збереження традицій сільських місцевостей, продиктованих кліматом, ландшафтом, та іншими подіями дають можливість розвивати туристичну інфраструктуру, що дасть вагомий внесок в розвиток країни (рис. 2). Відповідно, така система вимагає далеко не типового підходу у вирішенні розпланування території та забудови. Існування пострадянського спадку в більшості випадків у селах України зазнало суттєвої реновації. На це вливають сучасні економічні та соціальні процеси у суспільстві.

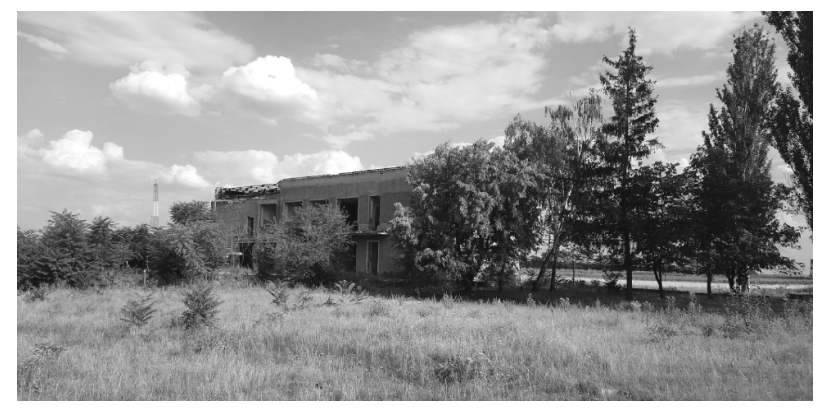

Рис. 1. Залишки адміністративного будинку виробничої зони у селі Чорноземне Запорізької області

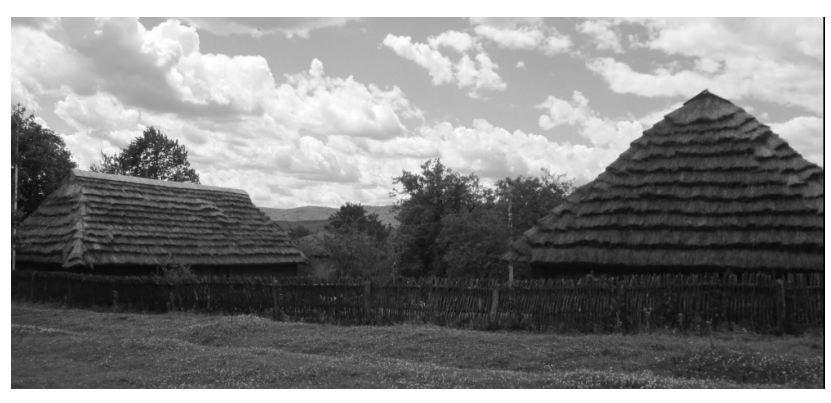

Рис. 2. Житлова забудова села Нагуєвичі Львівської області 
Питання вирішення забудови та розпланування сучасного села може вирішуватись 3 врахуванням детального аналізу, існуючого стану території. Всі складові населених пунктів, починаючи від стану вулиць та існуючих інженерних мереж до забудови, що вже існує є невід'ємними ланками. Якщо висвітлювати питання вуличної мережі, то якісний стан не відповідає сучасним вимогам експлуатації сучасної техніки (рис. 3,4 ). Недоліки є як у самій якості вуличного покриття, так і в особливостях розпланування, це стосується ненормованих профілів вулиць, невдалих розв'язок вузлових елементів (як композиційно, так і технічно).

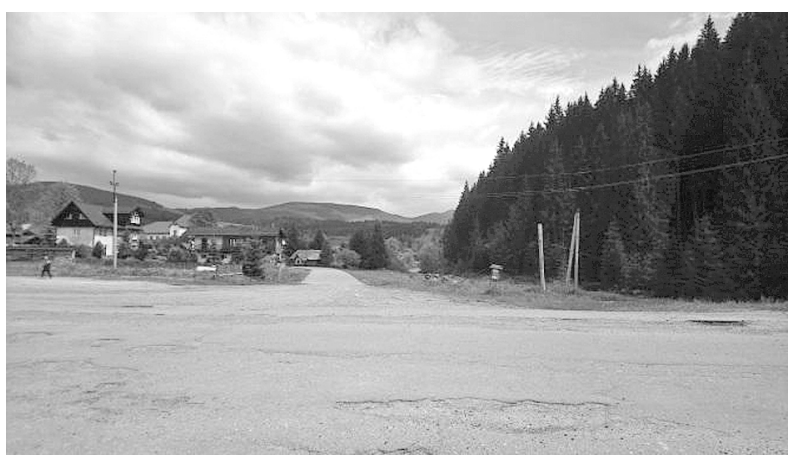

Рис. 3. Головна вулиия села Вишків Івано-Франківська область

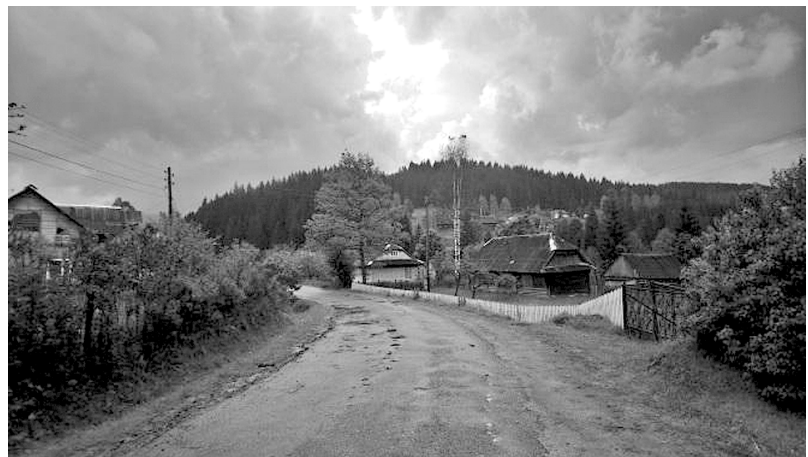

Рис. 4. Житлова вулиия села Вишків Івано-Франківська область

Важливим і невід'ємним елементом сучасного села $є$ його громадська забудова. Ряд реформ, які вже проводяться державою доводять, що сільські поселення потребують оновлення не лише в галузі технологічного обладнання, але й у структурі забудови в цілому. Вивчення сучасного стану забудови сільських поселень дає змогу вирішити ряд питань під час проведення робіт з їх реконструкції і реновації. Створення сприятливих соціальних умов є однією з найважливіших ланок у загальнодержавному реформуванні сільського життя, що сприятиме подальшому розвитку найкращих умов для збалансованого сільського життя пересічних його мешканців. Одним з методів вирішення зазначеної проблеми є влаштування культурно-побутових, адміністративних, освітніх закладів на теренах сільських поселень, благоустрою територій для активного та тихого відпочинку. Створюючи громадський центр поселення, необхідно вирішити цілий ряд завдань: доцільність розташування в архітектурно-планувальній структурі населеного пункту; підбір будівель, що будуть включені в забудову центру за своїм складом, враховуючи чисельність мешканців; формування архітектурно-планувальної структури центру, що відповідає складеній ситуації; встановлення його оптимальних параметрів, що забезпечують нормальне функціонування і доцільність сприйняття; пошук композиційного рішення, що виділяється виразністю та гармонійністю. Проблемою в деяких селах є відсутність культурно-побутової інфраструктури. Бородіна I. та Прокопа О. поділяють населені пункти на сім характерних груп за рівнем забезпеченості об' єктами сфери обслуговування. Згідно з дослідженнями 25,4 \% усіх сільських населених пунктів України не мають жодного об'єкта сфери обслуговування і тут проживає $2,5 \%$ сільського населення. Низький рівень забезпеченості згаданими об’єктами є у $25,8 \%$, середній $28,0 \%$, а більш-менш достойний показник забезпеченості лише у $30,3 \%$ де проживає 48,6 \% сільського населення (Костюченко Д. Л., 2017).

Висвітлена статистика не відтворює проблем в архітектурно-планувальній структурі сільських поселень. Досвід забудови українських сіл підтверджує важливість детального аналізу кожного окремого поселення 3 врахуванням всіх його особливостей. Розпланування сільського поселення $\epsilon$ нероздільним 3 природно-ландшафтною структурою та особливостями господарювання населення. 
На сучасному етапі також з'являються проблеми з вирішенням забудови поселень, що є під впливом великих урбанізованих просторів. Ці поселення поєднують в собі території сільськогосподарського та виробничого призначення, виконують великий набір функцій, що не завжди вдало поєднуються і позитивно впливають на рівень життя самих селян. В сучасних умовах розвитку великих міст - урбанізованих просторів відбувається цілий ряд процесів, що послідовно впливають не тільки на саме існування міста, але й на прилеглі території і суміжні поселення. Сільські території забудовують відпочинковими комплексам, готельними господарствами, житловими котеджами (рис. 5). Забудова часто ведеться без системного поквартального вирішення, в поселеннях відсутнє чітке функціональне зонування. Територіальний розвиток потребує вивчення всіх процесів та взаємовпливів для складання оптимальної майбутньої містобудівної моделі. Вирішення схем функціонального зонування сільських поселень 3 врахуванням обслуговуючої інфраструктури та виявлення проблем у розвитку зв'язків між його складовими, а також методів оптимізації простору. Виникає суперечність сільських територій і промислово орієнтованої інфраструктури, що формує поняття “місцева економіка", в якій вже можуть вироблятися продукція і послуги. Враховуючи етапи урбанізації простору, виникає необхідність у створенні віртуальних моделей розвитку територій, 3 прогнозованими напрямками розвитку як житлових територій, так i зон з виробничим і господарським призначенням.

На думку зарубіжних вчених, політика сільського розвитку полягає у мобілізації зусиль, спрямованих на ліквідацію або мінімізацію соціальних та економічних недоліків, які знижують якість життя сільських громад (Bamidele А., 1990). Досвід встановлення позитивного розвитку культури та побуту населення свідчить про взаємозв'язок цього процесу з економічним ростом життя.

Вітчизняний досвід вирішення громадської інфраструктури у сільських поселень є сформованим у Радянський період і потребує новітнього підходу та переосмислення з врахуванням сучасних потреб населення. Формування великих монументальних площ на цьому етапі $€$ неактуальним і необгрунтованим при вирішенні раціонального вирішення забудови сіл (рис. 6, 7). Забудова великих об'єктів культурно-громадського призначення також не має на сьогодні вдалого використання (рис. 8, 9).

Двоповерхові громіздкі будівлі клубів, будинків просвіти невдало вписуються в сільські ландшафти. Експлуатація та обслуговування пострадянської забудови також створює багато проблем для селян (рис. 9).

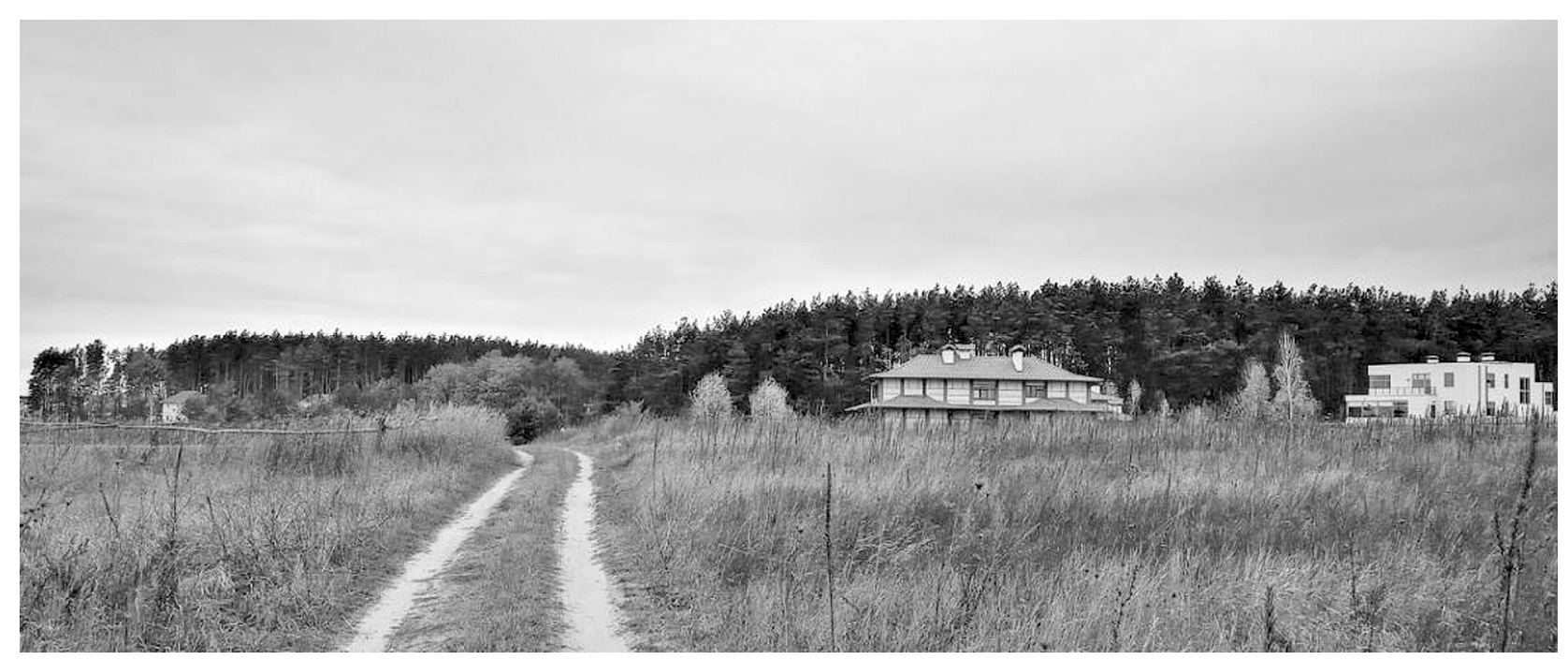

Рис. 5. Житлова забудова в селі Колонщчина Київської області 


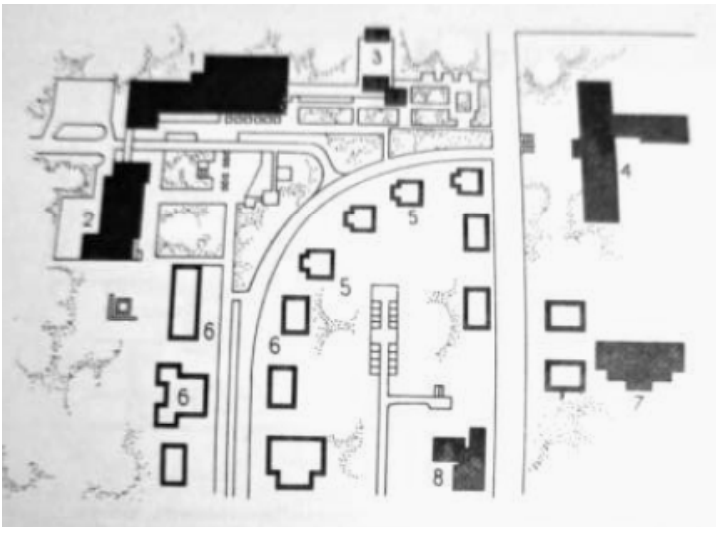

Рис. 6. Планувальна схема громадського ичентру с. Ратнів Волинської області

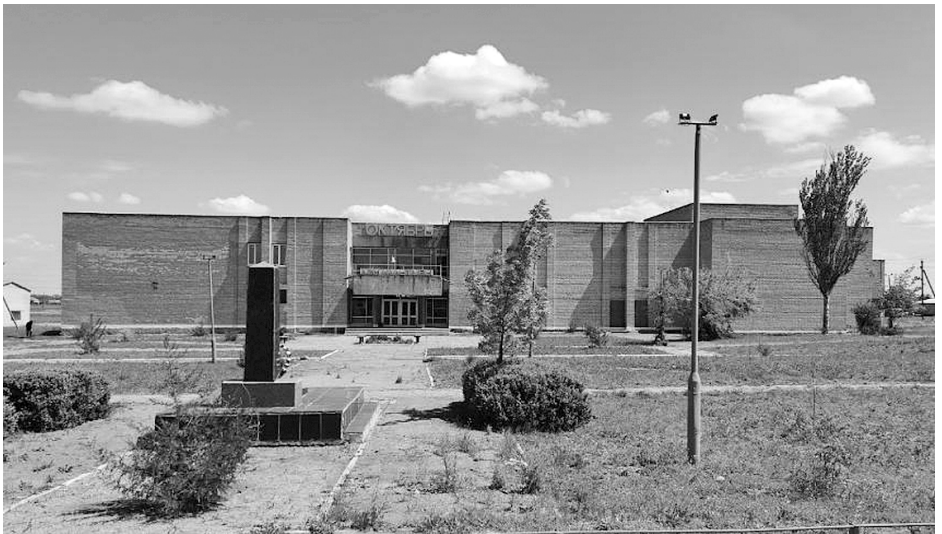

Рис. 8. Будинок культури в селі Чорноземне Запорізької області

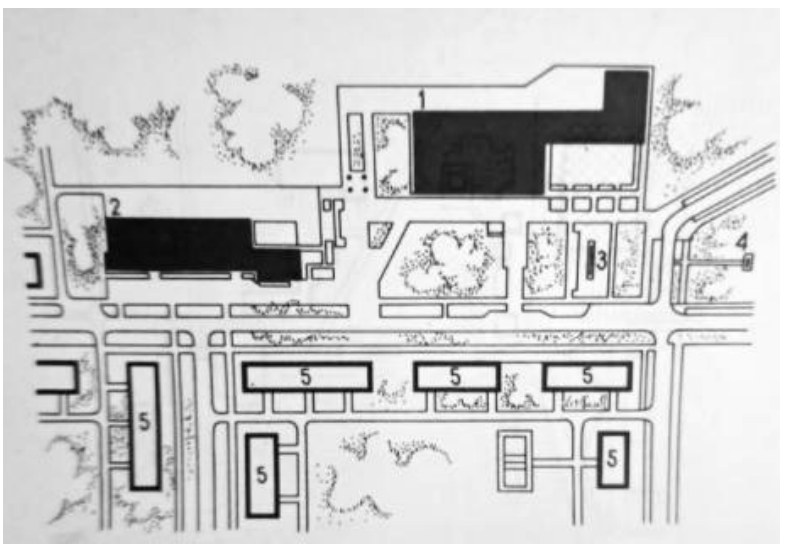

Рис. 7. Планувальна схема ичентру села Сніжків, Харківська область

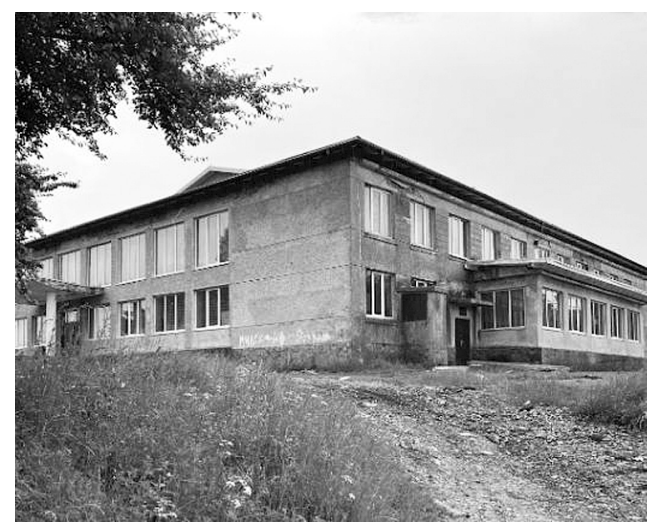

Рис. 9. Будинок культури села Добростани Львівської області

\section{Висновки}

Робота, яка ведеться в напрямку реновації існуючих сільських поселень повинна враховувати широкий перелік факторів: існуюче природно-кліматичне середовище, традиції місцевого населення, існуюча інфраструктура як культурно-побутова, так і господарська, розташування в структурі адміністративного розпланування та взаємовплив прилеглих територій тощо.

Враховуючи намічену стратегію соціально-економічного розвитку, територій сільських поселень варто звернути увагу на вже існуючий досвід з позитивними і невдалими результатами архітектурно-планувальної, економічної та соціальної політики розвитку сільських поселень України. Індивідуальний підхід при вирішенні планування поселень забезпечить подальший розвиток не лише у містобудівному напрямку та його реновацію, але й створить сприятливі умови для достойного рівня життя селян та продуктивної сільськогосподарської діяльності.

\section{Бібліографія}

Габрель М. М. 2004. Просторова організаиія містобудівних систем. Київ : Ін-трегіон. досліджень НАН України : А.С.С.

Гнесь Л. Б. 2017. Природно-ландшафтні чинники у розплануванні українського села. Вісник Львівського наиіонального аграрного університету: архітектура і сільськогосподарське будівниитво. Львів : № 18. C. $127-131$.

Кравченко В. Я. 1969. Планіровка і забудова центру села. Київ : Будівельник.

Костюченко Д. Л. 2017. Розвиток сільських територій в Україні: проблеми та перспективи. Ефективна економіка. № 4. [online]. Доступно: http://www.economy.nayka.com.ua/?op=1\&z=5556 
Лоїк Г. К., Шульга Ю. М. 2003. Село українська архітектурна традиція. Архітектура: зб. наук. праџь. № 486. Львів : Вид-во Нац. ун-ту “Львівська політехніка”. С. 348 -359.

Маханько Б. А., Моисеева С. Б., Плотникова А. С. 1982. Архитектурно-планировочная структура общественных цеентров сельских поселков. Москва : Стройиздат. 108 с.

Мазур А. Г., Дмитрик О. В. 2016. Господарства населення як економічна категорія та суб'єкт облаштування сільських територій. Економіка. Фінанси. Менеджмент. № 11. [online]. Доступно: http://efm.vsau.org/ files/pdfa/3392.pdf

Мазур С. А. 2017. Інфраструктурне забезпечення розвитку сільських територій. Економіка. Фінанси. Менеджмент. No. 3 [online]. Доступно: http://efm.vsau.org/files/pdfa/3542.pdf

Закон України “Про затвердження Державної иільової програми розвитку українського села на період до 2015 року” [online]. Доступно: http://zakon1.rada.gov.ua/laws/show/1158-2007-\%D0\%BF/page4

Сільник О. I. 2018. Архітектурно-планувальна композиція у формуванні сільських поселень України. Вісник Львівського національного аграрного університету: архітектура і сільськогосподарське будівництво. № 19. C. 144-146.

Bamidele A. 1990. Universal concept of rural development problems: An analysis in Onajide M.O. et. fl. P. 3-25.

\section{References}

Habrel' M. M. 2004. Prostorova orhanizacija mistobudivnyx system. Kyjiv. NAN Ukrajiny, In-trehion. doslidžen' : A.S.S.

Hnes' L.B. 2017. Pryrodno-landšaftni čynnyky u rozplanuvanni ukrajins'koho sela. Visnyk L'vivs'koho nacional'noho ahrarnoho universytetu: arxitektura i sil's'kohospodars'ke budivnyctvo. No. 18. L'viv. S. $127-131$.

Kravčenko V. Ja. 1969. Planirovka i zabudova centru sela. Kyjiv : Budivel'nyk.

Kostjučenko D. L. 2017. Rozvytok sil's'kyx terytorij v Ukrajini: problemy ta perspektyvy. Efektyvna ekonomika. № 4, [online]. Dostupno: http://www.economy.nayka.com.ua/?op=1\&z=5556

Lojik H. K. Šul'ha Ju. M. 2003. Selo ukrajins'ka arxitekturna tradycija. Arxitektura: zb. nauk. prac'. № 486. L'viv : Vyd-vo Nac un-tu “L'vivs'ka politexnika”. S. 348-359.

Maxan'ko B. A., Moyseeva S. B., Plotnykova A. S. 1982. Arxytekturno-planyrovočnaja struktura obščestvennblx centrov sel'skyx poselkov. Moskva : Strojyzdat. $108 \mathrm{~s}$.

Mazur A. H., Dmytryk O. V. 2016. Hospodarstva naselennja jak ekonomična katehorija ta subjekt oblaštuvannja sil's'kyx terytorij. Ekonomika. Finansy. Menedžment. No. 11. [online]. Dostupno: http://efm.vsau.org/ files/pdfa/3392.pdf

Mazur S. A. 2017. Infrastrukturne zabezpečennja rozvytku sil's'kyx terytorij. Ekonomika. Finansy. Menedžment. No. 3 [online]. Dostupno: http://efm.vsau.org/files/pdfa/3542.pdf

Zakon Ukrajiny "Pro zatverdžennja Deržavnoji cil'ovoji prohramy rozvytku ukrajins'koho sela na period do 2015 roku” [online]. Dostupno: http://zakon1.rada.gov.ua/laws/show/1158-2007-\%D0\%BF/page4

Sil'nyk O. I. 2018. Arxitekturno-planuval'na kompozycija u formuvannja sil's'kyx poselen' Ukrajiny. Visnyk L'vivs'koho nacional'noho ahrarnoho universytetu: arxitektura i sil's'kohospodars'ke budivnyctvo. No. 19. S. 144-146.

Bamidele A. 1990. Universal concept of rural development problems: An analysis in Onajide M.O. et. fl. P. 3-25.

Oleksandra Silnik

Associate Professor of the Department of Architecture and Planning of rural settlements, Lviv National Agrarian University, Dublyany e-mail: silnikoleksandra@gmail.com orcid: 0000-0003-4546-3319

\section{TRENDS OF DEVELOPMENT AND DIRECTIONS OF RENOVATION OF RURAL SETTLEMENTS OF UKRAINE}

(C) Silnik O., 2020

The rural settlement occupies a very important place in the modern socio-cultural structure of our state. Ukraine has a huge agricultural potential, and rural development has a significant impact on the economic situation. An important task of society is to increase the quality of life of its inhabitants. The comfort of rural 
settlements is influenced by the quality of housing, the level of cultural and industrial infrastructure. Domestic and foreign experience confirms the importance of the development of rural entrepreneurship, services, cultural education.

The issue of solving the construction and planning of a modern village can be solved taking into account detailed analysis of the existing state of the territory. All components of settlements, from the condition of streets and existing utilities to existing buildings, are integral parts. If we cover the issues of the street network, the quality does not meet the modern requirements for the operation of modern equipment. The disadvantages are both in the quality of the street pavement and in the peculiarities of the layout, this applies to unregulated street profiles, unsuccessful junctions of nodal elements. Construction and development of public buildings in modern villages of Ukraine also do not meet the needs of modern residents of settlements. A number of reforms already underway by the state prove that rural settlements need to be renewed not only in the field of the technological equipment but also in the structure of construction in general. One of the methods of solving this problem is the arrangement of cultural and domestic, administrative, educational institutions in rural areas, landscaping for active and quiet recreation.

At the present stage, there are also problems with solving the development of settlements, which are under the influence of large urban areas. These settlements combine agricultural and industrial areas, perform a wide range of functions that are not always successfully combined, and have a positive impact on the living standards of the peasants themselves. Given the current stages of transformation of settlements in modern conditions, there is a need to create virtual models of development of areas with projected areas of development of both residential areas and areas with industrial and economic purposes.

Work on the renovation of existing rural settlements should take into account a wide range of factors: the existing natural and climatic environment, traditions of the local population, existing infrastructure, both cultural and economic, location in the structure of administrative planning, and interaction of adjacent territories, etc.

Key words: village, settlements, architectural and planning structure, cultural and household infrastructure, rural settlement, renovation. 